\title{
Environmental History of Marine Mammal Exploitation in Trinidad and Tobago, W.I., and its Ecological Impact
}

\author{
ALDEMARO ROMERO ${ }^{1}$ \\ RUTH BAKER \\ JOEL E. CRESWELL
}

Environmental Studies Program and Biology Department

Macalester College

1600 Grand Ave.,

St. Paul, MN 55105-1899, USA

\author{
ANURADHA SINGH \\ Department of Life Sciences \\ University of West Indies \\ St. Augustine \\ Trinidad \& Tobago, W.I.
}

\author{
ANNABELLE MCKIE \\ MICHAEL MANNA \\ Department of Biology \\ Florida Atlantic University \\ Boca Raton, FL, USA
}

\begin{abstract}
Marine mammal exploitation has been documented for the Caribbean in recent times for only a handful of countries. Based on those studies a complex image of how that exploitation has taken place has begun to emerge. In order to fully understand whaling, dolphin fisheries, and manatee hunting, we still need to ascertain patterns of exploitation for many of the island-nations in that part of the world. We present a comprehensive analysis of marine mammal utilisation for Trinidad and Tobago. Trinidad and Tobago has been characterised by landbased whaling, organised during most of the nineteenth century by local elites. Dolphin fisheries have been rare and restricted to by-catches. Trinidad has the last remaining population of manatees among the eastern Caribbean islands, which is composed of a small number of individuals confined to a small swamp.
\end{abstract}


We compared the history, patterns, and results of this exploitation in Trinidad and Tobago with other neighbouring nations (Venezuela, Grenada, and St. Vincent and the Grenadines). As in other countries in the area that practised intense whaling, local populations of humpback whales have become virtually extinct in their waters. Culture, more than anything else, seems to be the force shaping the nature of marine mammal exploitation in the Caribbean, which has resulted in different histories and methods of exploitation for each one of the countries studied.

\section{KEY WORDS}

Historical ecology, marine mammal exploitation, whaling, dolphin fisheries, conservation, Caribbean, Trinidad and Tobago

\section{INTRODUCTION}

In order to better understand ecological modifications at large temporal scales we need to apply a historical perspective. ${ }^{2}$ That means that increasingly we have to use palaeoecological, archaeological, and historical data in order to extend ecological records back long enough to understand changes on natural resources through time. ${ }^{3}$ This approach has already been successfully employed for reconstructing the pre-Columbian conditions of coastal ecosystems for the northern Caribbean ${ }^{4}$ and for specific resources such as pearl-oyster beds along the northern coasts of South America. ${ }^{5}$ Also, the incorporation of environmental background when interpreting history is becoming more commonplace. ${ }^{6}$

The arrival of Europeans on the American continent offers a good opportunity to analyse neoextinctions. Post-Columbian extinctions are not only more recent in time but also much better documented from a historical perspective, providing us with the opportunity to understand the interplay of social and ecological factors. For example, the history of marine mammal (cetaceans, seals, and manatees) exploitation for many parts of the Caribbean is poorly known. West Indian manatee (Trichecus manatus manatus) exploitation has taken place since pre-Columbian times and most populations have been extirpated by now. ${ }^{7}$ Organised commercial whaling and dolphin fisheries have existed in the southern and eastern Caribbean for at least two centuries. ${ }^{8}$ From a recent review of published literature on marine mammals for the Caribbean, ${ }^{9}$ it can be concluded that the islands of Trinidad and Tobago are probably among the least known for their marine mammal diversity and utilisation in that part of the world. Despite the fact that a number of whaling operations took place during the nineteenth century, the information is scant, especially when dealing with the exploitation of small species of marine mammals. Further, in recent years, an increasing 
number of Caribbean countries have joined the International Whaling Commission and have stated their intention to resume whaling and/or support the return to commercial whaling by other nations. ${ }^{10}$ Thus, more comprehensive and upto-date information is needed regarding the marine mammals utilisation for this area.

The aim of this article is to document the past and present of both the exploitation practices and the conservation status of marine mammals in Trinidad and Tobago. This is part of a long-term study on the distribution and conservation status of cetaceans in the Caribbean. Studies for Venezuela and Grenada have been completed and published. ${ }^{11}$ Here we provide all available historical records of marine mammal utilisation for Trinidad and Tobago and then analyse this information within its own historical context.

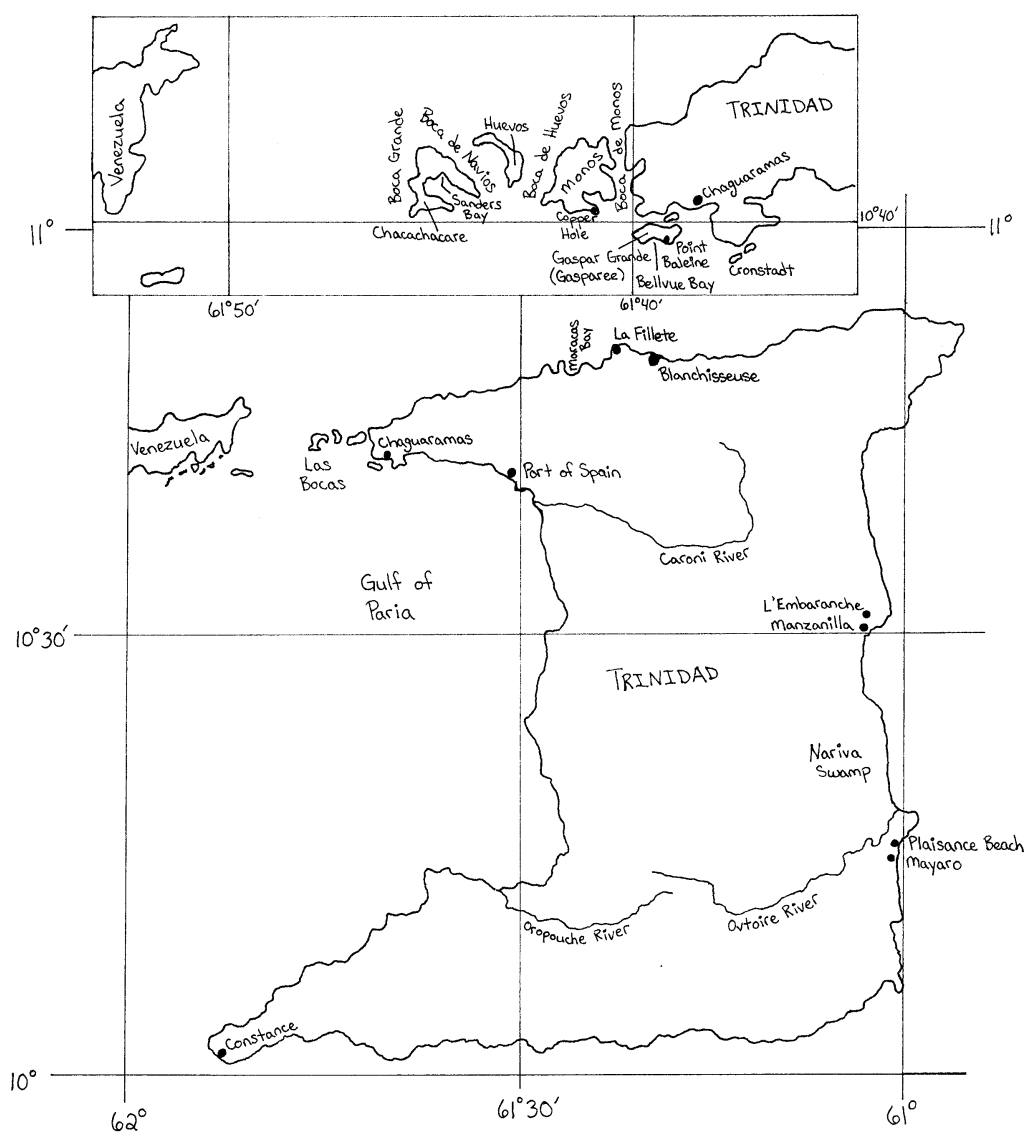

FIGURE 1. Map of Trinidad, including the localities mentioned in the text. 


\section{METHODS}

This paper is largely based on field and archival studies carried out between the 8 and 20 January 2000 and 12 and 24 March 2001. We explored all known landbased whaling sites, all of them located in the north-western area ('Bocas') of Trinidad (Figure 1), where we examined all possible remains of whaling operations. Any indication of whaling activity in the area was photographed and/ or videotaped. We also visited the National Library, National Archives, the National Museum at Port-of-Spain, the West Indiana Library Collection at the University of the West Indies in St. Augustine, the Biology Seminar Library of the same university, the Library of the Institute of Marine Affairs, and the archives of the Wildlife Division and the Fisheries Division. There, we examined every available publication, record or remain related to marine mammals. All pertinent documentation was photocopied, scanned and electronically stored, photographed, and/or video taped.

We also visited the following fishing towns: Maracas Bay, La Filette, and Blanchisseuse (in Trinidad) and Castara Bay, Speyside, and Charlottesville (in Tobago) (Figures 1 and 2). We interviewed the fishers from those localities about

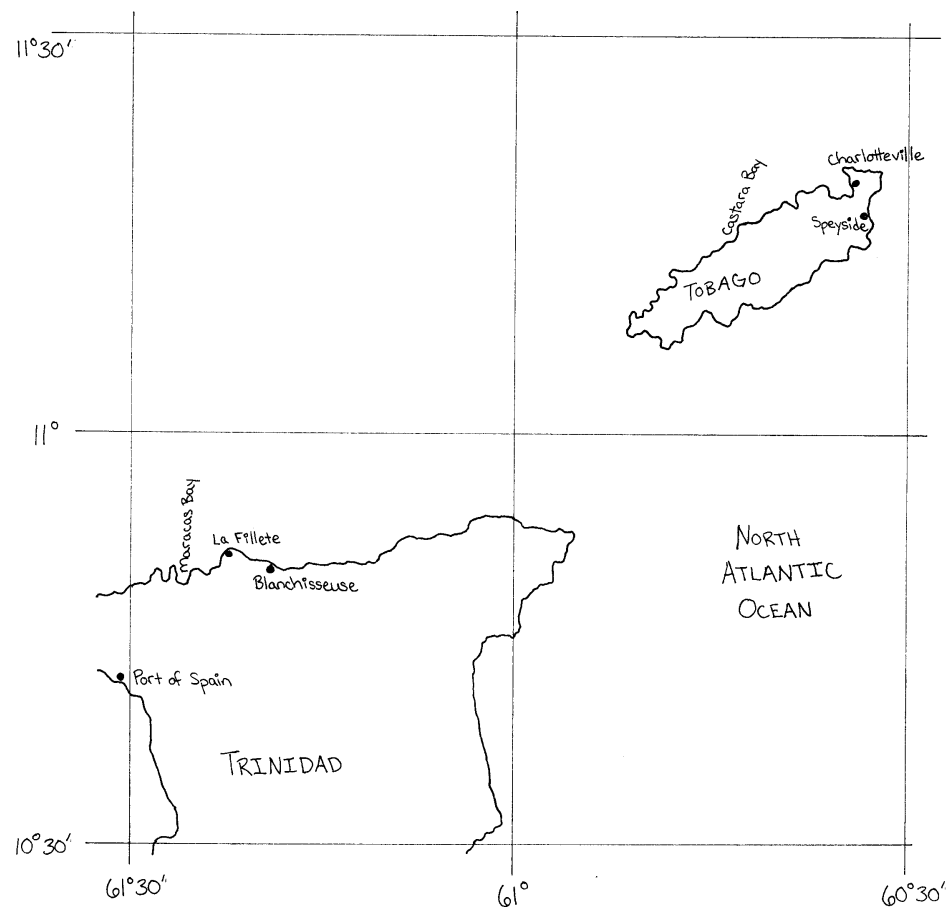

FIGURE 2. Map of Tobago, including the localities mentioned in the text. 
past and present marine mammal utilisation. ${ }^{12}$ We visited the Nariva Swamp where has been reported the last remaining population of manatees for Trinidad. ${ }^{13}$ Toponyms were used based on official Trinidadian maps: Directorate of Overseas Surveys for the Government of Trinidad and Tobago Sheets 4, 11, 12, 36,46 , at a scale $1: 25,000$.

\section{RESULTS AND DISCUSSION}

\section{Historical Account}

\section{Pre-Columbian Era}

There is only one piece of evidence of possible utilisation of cetaceans by preColumbian inhabitants of Trinidad: remains of an unidentified cetacean from St. Joseph (the first Spanish capital of Trinidad) on a branch of the Caroni river on the south side of the North Range..$^{14}$ There is no indication on the type of capture.

\section{Land-Based Commercial Whaling}

European knowledge about cetaceans in the waters of Trinidad and Tobago is presumed to have begun with Christopher Columbus naming the Gulf of Paria as 'Golfo de la Ballena' (Whale's Gulf), although from reading his diary it is not clear whether or not he saw whales in those waters. ${ }^{15}$

Equally unclear is when commercial whaling began in the area. According to a display at the National Museum at Port-of-Spain, 'Whaling was one of the earliest industries of Trinidad. A whaling station existed at Bulmera Bay, Chaguaramas in 1775. The whales were sighted at Bob Rocks, which was named after the female slave, Bolo, a whale watcher who gave the signal of a sighting by blowing a conch shell.' This reference does not seem reliable for a number of reasons. First, in 1775 Trinidad was still under Spanish rule and there is no historical record of the Spaniards ever been involved in whaling in the American continent other than through Basque whaling along the eastern coasts of North America. Second, we examined a map of Chaguaramas dated $1792^{16}$ deposited at the U.S. Library of Congress and could not find any indication of a whaling station in that locality. Third, we could not find the author or the source of this display. Finally, none of the sources consulted for this paper mentioned in any way such an operation. ${ }^{17}$

Commercial whaling most likely began around 1826. In that year, C.A. White, a retired sea Captain from Bermuda, bought 17 quarrees (55 acres) of land on the flat westernmost tip of Gasparee (Gaspar Grande), from a Trinidadian, Mr. de Percin. This land later came to be known as Pointe Baleine (Whale Point) and in May 1827, White petitioned the Cabildo (Port-of-Spain Council) for permission to open a subscription list to establish a whaling industry..$^{18}$ The 
Cabildo granted his request, since they felt it would not interfere with their sale of coconut oil from Manzanilla on eastern Trinidad; the 2,400 gallons they produced each year could not satisfy local demand for lamp oil. White appointed Charles Hugon as his sales agent. ${ }^{19}$ A 15 March 1826 article describes the first whaling operation as follows:

Sometime ago we noticed the introduction of the Whale Fishery in this Gulph:20 and we have much pleasure in stating that the commencement of the undertaking affords every prospect of success and profit to the enterprising speculators. In the beginning of last week the arrangements were completed, boiling houses \& c. having been erected of the west end of the Island of Gasparee: and the sloop Mary \& Lucy Ann and two whale boats commenced the fishing on Thursday last, and in a short time two large whales were struck but owing to delay on the part of the boats, both made their escape. On the same day, however, a small one was struck and taken; and on Monday morning the boats took two large whales to the works. On Saturday and Sunday a number of residents of Port-of-Spain visited the works, which with the rest of the apparatus, we are informed are very complete. ${ }^{21}$

Shortly after this notice, local newspapers published a series of advertisements for 'Whale oil the produce of the Trinidad Whale Fishery' for sale as well as 'Spermaceti candles'. ${ }^{22}$ To accommodate these activities, a ferry service was introduced in the late 1820s, with the S.S. Woodford facilitating movement of produce and people between the islands and the mainland. ${ }^{23}$ In 1830 between 14 and 15 whales were killed using one boat and Trinidadian whale oil was priced at half the international market price ${ }^{24}$ while importation of whale oil dropped sharply by that year. Most oil was used for burning in lamps and (mixed with honey) as flu remedy. Although most oil was locally consumed, some was exported (mostly to British colonies) and whalebone was also sent to London. ${ }^{25}$ All land-based whaling took place in the island of Trinidad and there is no indication that such operations ever took place in Tobago.

These operations must have required extensive local investment, given that from the beginning we find the names of upper-class Trinidadian families involved in this business. By the 1830s, the whole whaling industry had expanded into four stations: two on the north coast of Gasparee Island or Gaspar Grande (1040'00" N, 61 39'55" W), one being at Point Baleine, mentioned earlier, owned and managed by White and the other presumably at the present Belle Vue Bay owned by the Tardieu family. ${ }^{26}$ The third was located at Copperhole (or Jenny Point) at Monos Islands (1040'30" N, 61 $41^{\circ} 00^{\prime \prime} \mathrm{W}$ ) owned and managed by the Gerold family, ${ }^{27}$ and a fourth was established at Chacachacare Island (probably in what is today Sanders Bay at $10^{\circ} 40^{\prime} 15^{\prime \prime} \mathrm{N}$, $61^{\circ} 45^{\prime} 00^{\prime \prime} \mathrm{W}$ ), operated by members of the Gerold family and Friederich Urich who had formed a partnership in $1834,{ }^{28}$ but originally established by the Carige family. ${ }^{29}$ All of these were merchant and planter families. The Urichs had been 
involved in the coconut oil production and sales; therefore, they saw in the whale oil a way to expand their business. ${ }^{30}$ The development of commercial whale fisheries in Trinidad coincided with bad economic times for the island and with a decline in the local population between 1827 and $1833 .{ }^{31}$

The whale hunting method, as well as the whaling stations, ${ }^{32}$ were very primitive. They used 'pirougues' (wooden skiffs made of a hard, heavy wood, locally known as balata or poui, Tabebuia spp.) led by a captain at the stern, six stalwart oarsmen, and a harpooner in the bow. These boats were at the Bay, and when a whale was sighted a horn would be blown, signalling the crew, who all lived at the Bay, to run down the hill to man the boats, and push them off. When a cow was spotted with its calf, the whaler aimed at wounding the calf with the least possible injury in order to ensure that the mother could be easily approached and harpooned. A flag was stuck in the whale, the mouth was sewn up so it would not take in water and sink, and it was towed into the station. Local personnel worked for up to 24 hours at a time flensing the animal, as near to the shore as possible, and the slices of blubber were carried to the sugar coppers, for boiling to extract the oil. During this period, numerous sharks showed up to take bites out of the remains of the whales. Apparently they were so numerous that the whaling company had to employ men to kill them with harpoons and hatchets. The whaling season was between January and May. Between 1830 and 1862, the number of whales caught annually was between 20 and 35, the oil (about 20,000 gallons on average) was taken to Port of Spain, for export or local use as lamp oil or medicine-whale oil, and the meat was locally consumed. ${ }^{33}$

These whaling techniques may have been introduced by 'Old Abraham' a Bermudan whaler. ${ }^{34}$ In 1834, the Gerolds brought a professional harpooner from Germany and that same year asked the Governor Sir George Hill to refuse authorisation for the American Schooner Harmony, out of Nantucket, to whale in the Gulf. ${ }^{35}$

Kenny and Bacon (1981) say that the species exploited was 'pilot whales, Globicephala, although occasional sperm whales were taken', yet, the description of the whales in the contemporary records as well as the name used to identify them at that time ${ }^{36}$ lead us to believe that they were humpback whales, Megaptera novaeangliae. This is consistent with the fact that the whaling season coincided with the migration season of humpback whales into those waters. Further, pilot whales are not as productive in terms of blubber as humpbacks are.

Whaling operations continued until at least 1865 although there is some mention of operations as late as the $1870 \mathrm{~s} .{ }^{37}$ We and others ${ }^{38}$ have checked contemporary documents but have failed to find any evidence of commercial whaling after 1865 . From the 1870 s, on, there was an overproduction of whale oil which, together with kerosene being used for lamps fuel, brought prices down. ${ }^{39}$ Even if the local whale population had survived, its hunting would probably not have been commercially feasible. 
Today there is little left of these whaling operations. We found and videotaped three coppers and one container submerged just a few metres from the former Copperhole station, which had been thrown there when the station was converted into a Sea Scouts facility. ${ }^{40}$

\section{Yankee Whaling}

Activities by Yankee whaling ships for Trinidad and Tobago have been summarised elsewhere. ${ }^{41}$ All indications are that there was never much interaction between Yankee and land-based whalers. Yankee whaling in the area did not start until the 1830s, when their Trinidadian counterparts were already fully engaged in whale hunting. If anything, Yankee whaling may have furthered the whale population decline.

\section{Current Utilisation}

Whaling is no longer practised in the waters of Trinidad and Tobago. Baleen whales no longer frequent Trinidadian waters and are only seen in very few numbers around Tobago. We hypothesise that humpback whales have become extinct in the waters of Trinidad, particularly in the Gulf of Paria. This conclusion is supported by a number of facts: 1) With the exception of a possible, but unconfirmed, 1922 record $^{42}$ of what appears to be a humpback whale $(M$. novaeangliae) which, according to the caption, was washed up on the beach, there are no records of humpbacks or any large whale for the Gulf of Paria in the twentieth century; 2) our extensive interviews with local fishers revealed that none of them have ever seen or heard of any large whale being seen in the Gulf of Paria; 3) a visual and acoustic survey in March 2000 in the Gulf of Paria failed to produce any record of any large whale in that area. ${ }^{43}$

Based on the evidence presented in this paper and elsewhere, ${ }^{44}$ there is little question that humpbacks were very common in the Gulf of Paria during the nineteenth century. We also know that until 1926 they were common in the neighbouring island of Grenada. ${ }^{45}$ Therefore, it is worthwhile to speculate on the possible causes for their local extinction. A common hypothesis we have heard and read is that their local extinction was prompted by pollution. ${ }^{46}$ However, such disturbances are relatively new (post Second World War) and do not explain why they have not been seen since late last century.

The data presented in this paper is consistent with our hypothesis that these whales were driven into local extinction by the whaling operations described in this paper. Similar exploitation patterns were also responsible for the extinction of local populations of the same species in Grenada. ${ }^{47}$ Figure 3 shows the levels of whale captures. Despite the lack of information for some years, confirmed reports point to at least 500 whales being killed between 1826 and 1865 . To that we need to add catches by Yankee whalers. In the neighbouring island of 


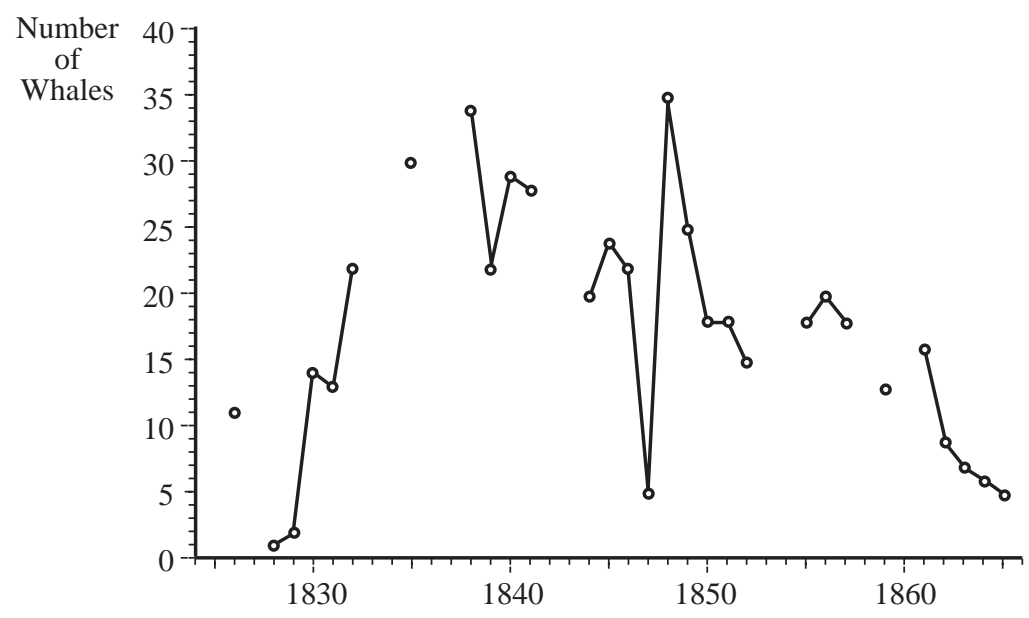

FIGURE 3. Confirmed whale catches for Trinidad based on Reeves et al. 2001. The solid line represents variations among consecutive years.

Grenada in 1925 and 1926, 102 and 72 humpbacks were taken respectively and that drove the local population to almost complete extinction, to the point that they are now very rare in those waters. ${ }^{48}$ Therefore, the number of $500+$ catches over a 40-year period is not an unreasonable foundation supporting our premises. Because of this lack of whales, whale-watching in the waters of Trinidad and Tobago is not a very likely activity.

Although official documents that we had the opportunity to review at the Wildlife Section casually mention that 'all cetaceans (are to be considered) endangered', the fact of the matter is that they lack legal protection under either the Fisheries Act (1980) or Conservation Wildlife Act (1980). Japan has requested the government of Trinidad and Tobago to join the IWC and to oppose the ban on commercial whaling. ${ }^{49}$ To date, the Trinidadian government has done neither.

\section{Dolphin Fisheries}

Dolphin fisheries have always been rare in Trinidad and Tobago waters. Reports of these activities are scant and most are related to accidental nettings. Earlier reports are from the beginning of this century ${ }^{50}$ and they relate to some occasional harpooning of 'porpoises'. There are also some more recent reports of 'porpoises' being occasionally harpooned in Tobago ${ }^{51}$ Our interviews with 
the local fishers have convinced us that active dolphin fisheries do not and have not taken place for many decades in Trinidad and Tobago in any significant way. The only place in which fishers were not totally forthcoming to us was in Charlottesville, Tobago, probably due to bad publicity regarding an incidental netting in the past. ${ }^{52}$

In general, dolphin fisheries in Trinidad and Tobago consist of incidental takings. Most animals that are captured are caught in Italian seines and sometimes in gill nets, at various locations. They are usually Stenella spp. and Tursiops truncatus. When captured, they are usually sold in the wholesale market, and may be seen occasionally offered on the roadsides on the north coast. ${ }^{53}$ They are sometimes labelled as 'shark' and sold as such but they are easy to distinguish from the latter because of their dark red, fatty and chewy meat. The dolphins are already dead when the nets are retrieved, but if still alive, they are killed. ${ }^{54}$ The largest animal ever taken in this way was an orca, Orcinus orca. That took place on 10 July 1987 . It was a $4.5 \mathrm{~m}$ female landed at the small boats jetty at Chaguaramas. The fisher reported that the whale had become entangled in his drift gill net as it was being hauled in. At the time he was out in the Gulf of Paria between Cronstadt and Gaspar Grande islands, in six-seven metres of water. The animal was a member of a pod numbering about $15 .^{55}$

On 16 October 1989, a local inhabitant of Mayaro, on the east coast of Trinidad, reported to the authorities that nine days earlier a ' 15 foot long dark brown whale came up in semi-drowned condition with harpoon hole about 4 feet from head. It came up at Plaisance Beach and was helpless. The villagers cut it up and utilised the meat and oil. It was apparently harpooned offshore' ${ }^{56}$

Another noted incident of opportunistic use of cetaceans took place on 1 May 1987, when a pod of 15 adults and two calves of short-finned pilot whales (Globicephala macrorhynchus) stranded at La Filette on the North Coast. All were returned to the sea except the two calves and one adult. The dead animals were taken to a fish market for sale. On 23 January 1987, an unidentified 'whale' (probably a pilot) was slaughtered by fishers and towed inland to Chaguaramas and its meat was placed on sale in the area. These reports exemplify the paucity and utilisation of marine mammals off the coasts of Trinidad.

Finally, we learned of a 'Dolphin Watch' operation at Charlottesville, Tobago. The owner of the boat told us that he had been doing it for three years taking people out to see what he identifies as bottlenose dolphins (T. truncatus). We could not ascertain the success of this operation which seems to be based on occasional presence of these animals in those waters.

\section{Manatee Exploitation}

Archaeological remains indicate that the West Indian manatee, Trichechus manatus manatus, was distributed along the Lesser Antilles and that they were used by the indigenous people inhabiting those islands. ${ }^{57}$ Historical accounts 
also support the contention that manatees were hunted, using harpoons, by the local inhabitants of that and neighbouring islands up to Colonial times. ${ }^{58}$

There are numerous reports of manatees being harpooned for their meat, oil, and hide from Colonial times until relatively recently ${ }^{59}$ (Figures 4 and 5). Today the only remaining area with manatees in Trinidad is the Nariva Swamp; 1997 survey revealed the presence of at least 18 individuals. ${ }^{60}$ This number is down from an estimation of 25-30 made in $1991 .{ }^{61}$ Records have also been made of unconfirmed reports by other fishermen from other east coast rivers, the Ortoire, south of the Nariva Swamp, and through the north, the North Oropouche River. ${ }^{62}$ In 1990 a manatee sighted at the L'Embaranche River was accidentally caught in a fishing net and butchered. ${ }^{63}$

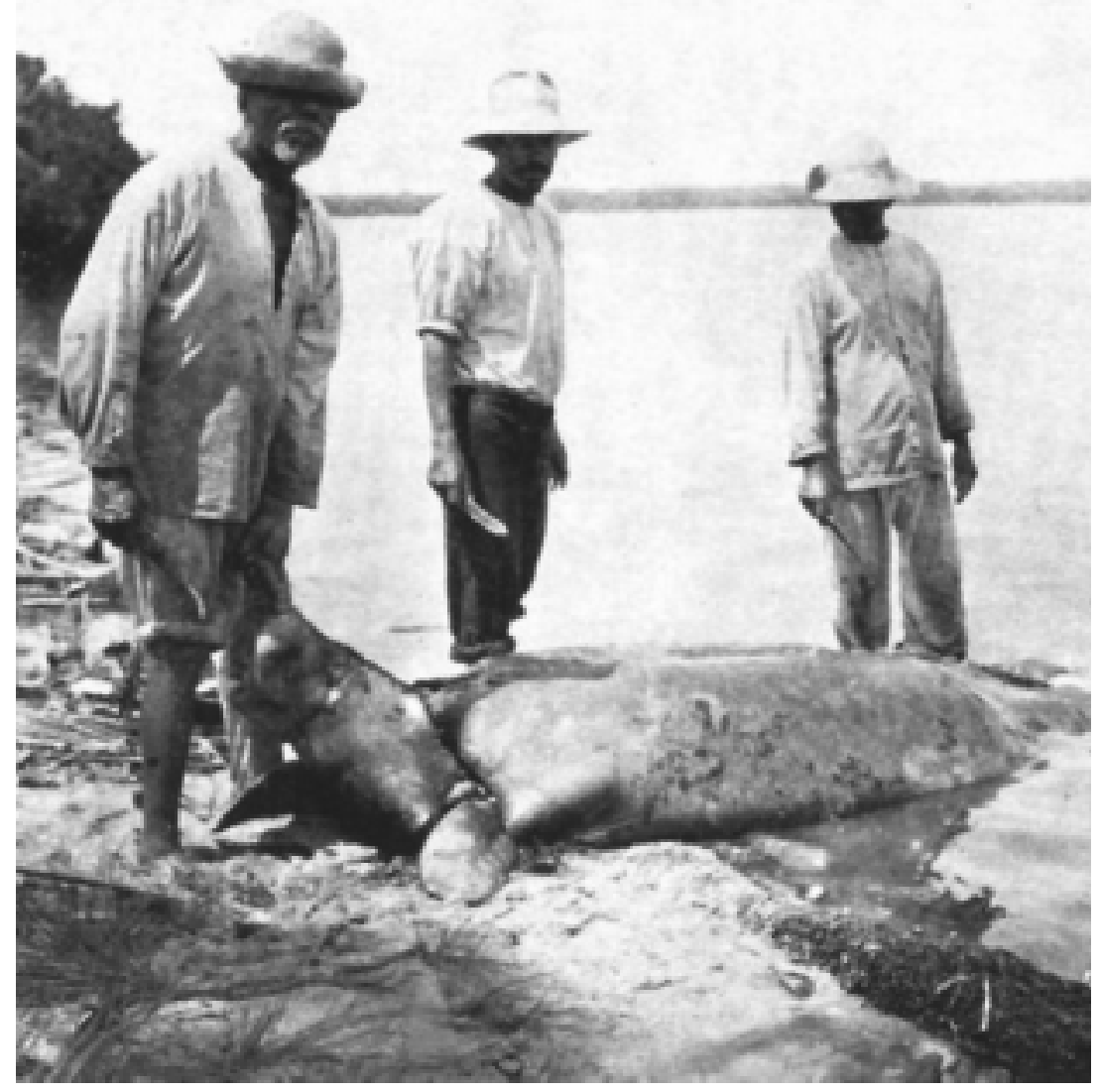

FIGURE 4. Picture of a manatee after being hunted around the turn of the century. Exact place and time of the picture are unknown. Picture found at the Library of the University of the West Indies in St. Augustine, Trinidad. 


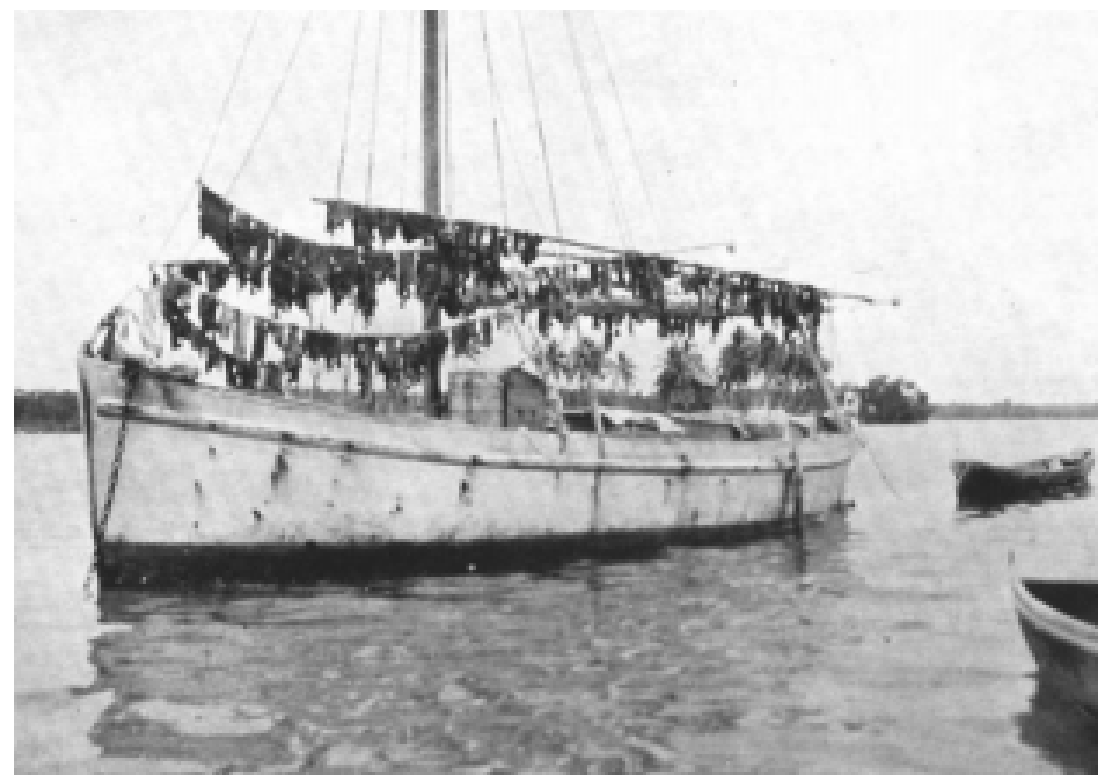

FIGURE 5. Picture of manatee hides hanging on a boat. This picture, taken around the turn of the century, shows that manatee hunting was more than and artisanal practice. Exact place and time of the picture are unknown. Picture found at the Library of the University of the West Indies in St. Augustine, Trinidad.

The manatee in Trinidad and Tobago is offered protection directly under the Conservation of Wildlife Act, Chapter 61:01. Under the provisions of this act, the manatee is considered a 'protected animal' and thus cannot be hunted at any time. Protection of the habitat and indirectly the manatee is also provided under the Forest Act Chapter 66: 01, with the Nariva Swamp dedicated as a Prohibited Area in April 1993. Although the manatee is offered protection under these two pieces of legislation, it is still threatened with extinction. The enforcement arm of the wildlife section cannot provide the required manpower to enforce laws. Therefore, poaching, squatting, incompatible agriculture practices, indiscriminate harvesting of mangroves and mining continue at an alarming rate. Accession to international treaties/conventions has been another management tool used to afford manatee protection. The Nariva swamp was named as a Ramsar site in $1993 .^{64}$ 


\section{CONCLUSIONS}

Marine mammal exploitation in Trinidad and Tobago is different from in neighbouring countries such as Venezuela, Grenada, and St. Vincent and the Grenadines. Table 1 compares the nature of such activities in those countries. Marine mammal exploitation in Venezuela has been largely restricted to dolphin fisheries. This activity was carried out for centuries and became a large scale operation beginning in the 1960s when vessels from Japan, South Korea, and Taiwan were given docking rights and subsidised fuel. Fishers from those countries extended this practice and the locals increased their dolphin capturing practices. They mostly used harpoons for capturing the animals and the most important product was meat for human consumption. Whaling in Venezuelan waters was practised only by Yankee whalers and only in occasional fashion. ${ }^{65}$ Marine mammal exploitation in Grenada was almost exclusively confined to whaling operations between 1925 and 1927 and was carried out by Norwegians who employed locals only in the processing of whaling products. Thus that country never developed a local culture of utilisation of these animals. ${ }^{66}$ Marine mammal exploitation for St. Vincent and the Grenadines commenced even before it did in Trinidad and continues to this day, although it was always very moderate in intensity. It has a wider range of species though since it has included both large whales and dolphin fisheries. They have mostly used harpoons regardless of the target species. While being heavily influenced by Yankee whalers in terms of the way boats were crewed and the type of harpoon used, it has almost always been carried out by local shore-based fishers. ${ }^{67}$

Trinidad and Tobago is particularly unique by the fact that whaling was developed essentially by local elites that employed slaves first and then labourers later to do the manual part of the job. Those elites were essentially planters, some of whom were already involved in the production of vegetable oil. By all accounts it was extremely rudimentary from a technological viewpoint, making it wasteful and uncoordinated. They also lacked the support of foreign investments. As in Grenada, exploitation ended when the local populations of humpback whales became either extinct or almost completely depleted. All that took place even before the prices for whale oil sank in the 1880s. Unlike Venezuela, dolphin fisheries in Trinidad and Tobago have always been marginal and largely confined to opportunistic utilisation as a result of by-catches.

The only common pattern we have found among Venezuelan, Trinidarian, and Grenadian marine mammal exploitation, has been the hunting of manatees. Manatee exploitation was practised in these three areas before the arrival of Columbus and the increase in human population accelerated their decline. Manatee hunting was carried out easily in all these countries using mostly harpoons and the meat, oil, and hide were almost always used. In a small island like Grenada, the local manatee population became extinct by the eighteenth century while the populations of this species became extremely depleted in both 


\section{ALDEMARO ROMERO ET AL.}

TABLE 1. Modes of exploitation of marine mammals in the southeastern Caribbean. Information for Venezuela is based on Romero et al. 1997 and Romero et al. 2001; for Trinidad and Tobago this paper; for Grenada based on Romero and Hayford 2001; for St. Vincent and the Grenadines on Rack 1952, Adams 1971, Adams 1973 and Beck 1986.

\begin{tabular}{|c|c|c|c|c|}
\hline & Venezuela & $\begin{array}{l}\text { Trinidad and } \\
\text { Tobago }\end{array}$ & Grenada & $\begin{array}{l}\text { St. Vincent and } \\
\text { the Grenadines }\end{array}$ \\
\hline \multicolumn{5}{|l|}{ Whaling } \\
\hline Nature & Locally absent & $\begin{array}{l}\text { Intense shore- } \\
\text { based }\end{array}$ & $\begin{array}{l}\text { Intense shore- } \\
\text { based }\end{array}$ & $\begin{array}{l}\text { Moderate shore- } \\
\text { based }\end{array}$ \\
\hline Period & $\mathrm{n} / \mathrm{a}$ & $1826-1865$ & $1925-1927$ & 1860s-present \\
\hline Induced by & $\mathrm{n} / \mathrm{a}$ & $\begin{array}{l}\text { Local planters } \\
\text { (elites) }\end{array}$ & Norwegians & Local fishers \\
\hline Yankee whaling? & $\begin{array}{l}\text { Very marginal } \\
1850 \mathrm{~s}-1870 \mathrm{~s}\end{array}$ & $\begin{array}{l}\text { Moderate } \\
1820 s-1870 \mathrm{~s}\end{array}$ & $\begin{array}{l}\text { Moderate } \\
1860 \mathrm{~s}-1880 \mathrm{~s}\end{array}$ & $\begin{array}{l}\text { Moderate } \\
1830 s-1880 s\end{array}$ \\
\hline Species & Humpbacks & $\begin{array}{l}\text { Almost all } \\
\text { humpbacks }\end{array}$ & $\begin{array}{l}\text { Almost all } \\
\text { humpbacks }\end{array}$ & $\begin{array}{l}\text { Mostly humpbacks, } \\
\text { some sperm }\end{array}$ \\
\hline Usage & Oil & $\begin{array}{l}\text { Oil, meat, } \\
\text { whalebone }\end{array}$ & $\begin{array}{l}\text { Oil, meat, } \\
\text { manure }\end{array}$ & Oil, meat \\
\hline Intensity & Minor & Significant & Significant & Significant \\
\hline Ecological effects & Very little (?) & Total depletion & Total depletion & Partial depletion \\
\hline \multicolumn{5}{|l|}{ Dolphin fisheries } \\
\hline Nature & Intense & Marginal & Absent & Significant \\
\hline Period & $\begin{array}{l}\text { Mostly 1960s- } \\
\text { present }\end{array}$ & $\mathrm{n} / \mathrm{a}$ & $\mathrm{n} / \mathrm{a}$ & 1920s-present \\
\hline Induced by & $\begin{array}{l}\text { Local and } \\
\text { Far-east fishers }\end{array}$ & Local fishers & $\mathrm{n} / \mathrm{a}$ & Local fishers \\
\hline Species & $\begin{array}{l}\text { Common, } \\
\text { Bottlenose }\end{array}$ & & & $\begin{array}{l}\text { Pilot, killer, Risso's, } \\
\text { Stenella spp. }\end{array}$ \\
\hline Capture method & $\begin{array}{l}\text { Harpooning, } \\
\text { nets, guns }\end{array}$ & $\begin{array}{l}\text { Harpooning } \\
\text { nets }\end{array}$ & & Harpooning, nets \\
\hline Usage & $\begin{array}{l}\text { Meat, oil, } \\
\text { artisanal }\end{array}$ & Meat & & Meat, oil \\
\hline Ecological effects & $\begin{array}{l}\text { Population } \\
\text { delpetion }\end{array}$ & $\begin{array}{l}\text { No noticeable } \\
\text { effects }\end{array}$ & $\mathrm{n} / \mathrm{a}$ & $?$ \\
\hline \multicolumn{5}{|l|}{ Manatee exploitation } \\
\hline Nature & Opportunistic & Opportunistic & Opportunistic & Absent \\
\hline Period & $\begin{array}{l}\text { Pre-Columbian } \\
\text {-present }\end{array}$ & $\begin{array}{l}\text { Pre-Columbian } \\
\text {-present }\end{array}$ & $\begin{array}{l}\text { Pre-Columbian } \\
\text {-18th century }\end{array}$ & \\
\hline Practised by & Locals & Locals & Locals & $\mathrm{n} / \mathrm{a}$ \\
\hline Capture method & Harpooning & Harpooning & Harpooning & $\mathrm{n} / \mathrm{a}$ \\
\hline Usage & Meat, oil & Meat, oil & Meat and oil (?) & $\mathrm{n} / \mathrm{a}$ \\
\hline Ecological effects & Largely depleted & Largely depleted & Extinction & $\mathrm{n} / \mathrm{a}$ \\
\hline
\end{tabular}


Venezuela and Trinidad. Manatees in Trinidad, although still present, seem to be in a very critical situation, confined to a small population in a very small area threatened by habitat destruction.

It is interesting to see how four neighbouring countries that share essentially the same marine mammal species ${ }^{68}$ developed different exploitation practices at different periods of time (Table 1). This strongly suggests that local culture shaped by history, more than anything else, was the main factor in the development of the type of marine mammal exploitation for each one of these countries.

\section{NOTES}

${ }^{1}$ Corresponding author.

${ }^{2}$ Meine 1999.

${ }^{3}$ Jackson, 2001.

${ }^{4}$ Jackson, 1997.

${ }^{5}$ Romero et al. 1999.

${ }^{6}$ See, for example, Ponting 1991, Sale 1991, Pastor Bodmer 1992, Simon 1997.

${ }^{7}$ McKillop 1985, Marsh and Lefebvre1994.

${ }^{8}$ Caldwell and Caldwell 1971, Mitchell 1975, Gaskin and Smith 1977, Perrin 1985, Price 1985, Reeves 1988, Romero and Hayford 2000, Romero et al. 1997.

${ }^{9}$ Romero et al. 2001.

${ }^{10}$ IWC 1997.

${ }^{11}$ Romero et al. 1997, Romero and Hayford 2000, Romero et al. 2001.

${ }^{12} \mathrm{We}$ used an abbreviated form of a questionnaire similar to the one described in Dolar et al. 1994.

${ }^{13}$ We want to thank the following people for their field assistance and information provided during our work in Trinidad and Tobago: Gary Aboud, Anthony de Verteuil, Kyla T. Hayford, Barry Higman, Mary Alkins Koo, Floyd Lucas, Joseph Mitchell, Gupti Lutchmedial, Kathleen Helense Paul, Mike Rogers, David Rooks, and Donna Spencer. Steven L. Swartz provided us with the galley proofs of the Reeves et al. (2001) article. Anna Payden drew the maps of Fig. 1 and 2. Field work for this research was supported by a Wallace Research Grant to A. Romero. We thank the personnel at the Department of Life Sciences of the University of the West Indies (St. Augustine) for logistical support. The Wildlife Section of the Forestry Division of the Government of Trinidad and Tobago granted the research permit. Hanne Eastwood and two anonymous reviewers read the MS and made valuable suggestions.

${ }^{14}$ Wing 1962.

${ }^{15}$ Columbus 1498/1986. He also gave the name of El Delfin (the dolphin) to the twin islands today known today as Huevos (Eggs), but not because of any dolphin or porpoise but because when seen from the westward it is very like a dolphin fish (Coryphaena spp.). See Sauer 1966.

${ }^{16}$ Anonymous 1792.

${ }^{17}$ For example, Borde (1876) who wrote the most comprehensive history of Trinidad under the Spanish government (until 1797), says nothing about that operation despite the fact that on page 3, he mentions the Golfo de la Ballena where 'it abounds with fish, and every year whales come to feed on the sea plants which grow there in abundance'. But then 
ALDEMARO ROMERO ET AL.

he adds ' These whales furnish a thick oil which is greatly priced'. Whether it is a general comments about whales or a tangential reference to whaling in Trinidad is unclear. According to Joseph (1838), the first whale fishery established in Trinidad was 'by a Mr. R. [Richard] Joell', but no date is cited. Joell is mentioned in some sources (Trinidad Guardian 20 June 1828) as selling whale oil. He would have been involved in hiring whale catchers for the operation at Gasparee Island (Point Baleine) (Port-of-Spain Gazette 24 Dec. 1833). All this may have led Joseph to believe that Joell was the initiator of commercial whaling in Trinidad.

${ }^{18}$ City Council Records 1827.

${ }^{19}$ Port-of-Spain Gazette 3 and 14 Mar. 1827.

${ }^{20}$ Port-of-Spain Gazette 3 and 14 Mar. 1827.

${ }^{21}$ Port-of-Spain Gazette, No. 51, Vol. 1, p. 2.

${ }^{22}$ E.g., The Port-of-Spain Gazette for Saturday, 18 Mar. 1826 No. 52, Vol. 1, p. 2.

${ }^{23}$ Costelloe 1998.

${ }^{24}$ Port-of-Spain Gazette. 5 May 1830. Whole \# 481. Vol 5, number 36.

${ }^{25}$ Reeves et al. 2001.

${ }^{26}$ Mostly Charles and Jean Baptiste, A. de Verteuil 1993.

${ }_{27}$ Jenny Point-Chaguaramas Assessment Roll 1884, Besson 1985, p. 122, includes picture.

${ }^{28}$ Carmichael 1961, de Verteuil 1994.

${ }^{29}$ A. de Verteuil 1986.

${ }^{30}$ A. de Verteuil 1994.

${ }^{31}$ A. de Verteuil 1975.

${ }^{32}$ See Trollope 1859 for the only contemporary account of the stations themselves.

${ }^{33}$ L.A.A. de Verteuil 1858, Ottley 1974, L. Fraser unpublished MS cited in de Verteuil 2000.

${ }^{34}$ de Verteuil 1986, de Verteuil 2000.

${ }^{35}$ Request to Governor-Trinidad Duplicated Despatches 1834.

36 'razor backs', Joseph 1838.

${ }^{37}$ A. de Verteuil 1993, de Verteuil 2000.

${ }^{38}$ Swartz et al. 2001.

${ }^{39}$ Archer 1881.

${ }^{40}$ Pers. comm. provided by local fishers.

${ }^{41}$ Reeves et al. 2001.

${ }^{42}$ A picture of four ribs and three vertebrae at Constance in the southwestern tip of Trinidad, ca. $10^{\circ} 03^{\prime} \mathrm{N}, 61^{\circ} 55^{\prime} \mathrm{W}$, de Verteuil 2000.

${ }^{43}$ Swartz et al. 2001.

${ }^{44}$ Romero et al. 2001.

${ }^{45}$ Romero and Hayford 2000.

${ }^{46}$ Swartz et al. (2001) hypothesised that the abandonment of the Gulf of Paria by humpbacks "could be attributable to disturbance from extensive oil and gas development and production that occurs off the southeastern end of Trinidad and in the southern Gulf of Paria, along with shipping traffic into and out of the Port of Spain harbor.'

${ }^{47}$ Romero and Hayford 2000.

${ }^{48}$ Romero and Hayford 2000.

${ }^{49}$ Araujo 1986.

${ }^{50}$ For example, Vincent (1910) mentions that "Sharks, sword-fish, saw-fish, and two kinds of porpoise locally called "marsouen blanc" (the small one) and "marsouen canal," 
weighing about three quarters of a ton, are plentiful, so the harpooner with a stout pirogue and four good oars can get plenty of fun'. This activity took place at the Bocas.

${ }^{51}$ Mendes 1932, Mendes 1937, Turpin 1978, Lee 1980.

${ }^{52}$ Turpin 1978.

${ }^{53}$ Kenny and Bacon 1981, pers. comm. by local fishers at La Blanchisseuse.

${ }^{54}$ Lee 1980, Gary Aboud, pers. comm.

${ }^{55}$ Ottley et al. 1994.

${ }^{56}$ Typewritten report at the Wildlife Section office, headed 'Harpooned whale. Date: 8910-16. Report received from Winsie Ali of Mayaro.'

${ }^{57}$ Ray 1960, Wing et al. 1968, Watters et al. 1984, Levebvre et al. 1989, Wing and Wing 1995.

${ }^{58}$ Du Tertre 1667, Dapper 1673, Labat 1742, Bullen 1964; Wing and Wing 1995; for additional citations on pre- and post-Columbus use of manatees in the Caribbean see McKillop 1985.

${ }^{59}$ M'Callum (1805) mentions the presence of this species on the coastal rivers in which they were captured by Indians and blacks using harpoons for meat consumption. L.A.A. de Verteuil (1884) cites this species as 'scarce' but being hunted for its meat. Kingsley (1871) and Collens (1892), both recorded the manatee in the Mitan (Nariva river). Collens (1892) mentions its capture not only for meat consumption but also for its oil which is very abundant in quantity, and in quality is not unlike cod liver oil'. Mole (1925) also indicated that the manatee was hunted as a source of food by the local population. Vincent (1910) mentions the use of manatee skin. An article published in the Port-of-Spain Gazette (6 Sept. 1925) cites the use of manatee skin to tie rafters in the early nineteenth century. As late as 1980 Trinidadian officials reported illegal hunting of these animals in the Nariva swamp (Lee 1980).

${ }^{60}$ Gupti Latchmedial, pers. comm.

${ }^{61}$ Boyle and Khan 1993.

${ }^{62}$ Amour 1993.

${ }^{63}$ Armour 1993.

${ }^{64}$ The Ramsar Convention on Wetlands of International Importance Especially in Waterfowl Habitat. Armour 1993.

${ }^{65}$ Romero et al. 1997.

${ }^{66}$ Romero and Hayford 2000.

${ }^{67}$ See Rack 1952, Adams 1971, Adams 1973, and Beck 1986.

${ }^{68}$ See Romero et al. 2001 for a comparison of cetacean species distribution among Caribbean countries.

\section{REFERENCES}

Adams, J. E. 1971. Historical geography of whaling in Bequia Island, West Indies. Caribbean Studies, 11: 55-74.

Adams, J. E. 1973. Shore whaling in St, Vincent island, West Indies. Caribbean Quarterly, 19: 42-50.

Anonymous. 1792. Plano geométrico de la Boca de Monos y puertos de Charguaramas y Carenero en la Ya. de Trinidad (unpublished map, at the Library of Congress, G5149.C53 1792). 


\section{ALDEMARO ROMERO ET AL.}

Amour, K.1993. Status of the West Indian Manatee (Trichechus manatus) in Trinidad and Tobago. Trinidad and Tobago: Forester I Wildlife Section, Forestry Division. Ministry of Agriculture, Land and Marine Resources. 14 September 1993.

Araujo, A. 1986. The problems associated with the international whaling industry and Trinidad and Tobago's involvement with the International Whaling Commission (unpublished report).

Archer, A.S. 1881. Sea-fishing in Barbadoes. The Field, The Country Gentleman's Newspaper (1054) (22 Oct.):592.

Besson, G. 1985. A Photographic Album of Trinidad at the Turn of the Nineteenth Century. Port-of-Spain, Trinidad: Paria.

Beck, H. P. 1986. "Bleows" The Whaling Complex in Bequia. Folklife Annual, 1986: 4261.

Borde, P. G. L. 1876 (1982). The History of the Island of Trinidad under the Spanish Government. 2 vols. Paris: Maisonneuve et Cie.

Boyle, C. and Khan, J. 1993. National Report of the status of the West Indian manatee in Trinidad and Tobago (unpublished). Manatee subcommittee, Trinidad Field Naturalist Club.

Bullen, R.P. 1964. The Archaeology of Grenada, West Indies. Contributions of the Florida State Museum, 11: 1-67.

Caldwell, D.K. and Caldwell, M.C. 1971. Porpoise Fisheries in the Southern CaribbeanPresent Utilizations and Future Potentials. In J. B. Higman (ed) Proceedings of the 23rd Annual Session of the Gulfand Caribbean Fisheries Institute, pp 195-206. Coral Gables, FL: University of Miami, Rosenstiel School of Marine and Atmospheric Sciences.

Carmichael, G. 1961. The History of the West Indian Islands of Trinidad and Tobago 1498-1900. London: Alvin Redman.

Collens, J. H. 1892. The Trinidad Manatee. Journal of the Field Naturalist Club, 1: $170-2$.

Columbus, C. 1498 (1986). Colón y el Viaje Tercero. Madrid: Pando Ediciones.

Costelloe, S. 1998. Scotland Bay - 1875 to the 1960s A family perspective (unpublished manuscript).

Dapper, O. 1673. Die unbekante neue Welt, oder Beschreibung des Welt-Teils Amerika, und des Sud-Landes. Amsterdam: J. von Meurs.

de Verteuil, A. 1973. Sir Louis de Verteuil. His Life and Times. Trinidad 1800-1900. Trinidad: Columbus Publishers.

de Verteuil, A. 1975. The Years Before. Port-of-Spain: Caribbean Ltd. Publishers.

de Verteuil, A. 1986. Sylvester Devenish and the Irish in Nineteenth Century Trinidad. Port-of-Spain: Paria Publishing Co. Ltd.

de Verteuil, A. 1993. Scientific Sorties. Port-of-Spain: The Litho Press.

de Verteuil, A. 1994. The Germans in Trinidad. Port-of-Spain: The Litho Press.

de Verteuil, A. 2000. Great Estates of Trinidad. Port-of-Spain: The Litho Press.

de Verteuil, L. A. A 1858. Trinidad: Its Geography, Natural Resources, Administration, Present Condition, and Prospects. London: Ward and Lock.

de Verteuil, L. A. A. G. 1884. Trinidad: Its Geography, Natural Resources, Administration, Present Condition, and Prospects. London: Cassell \& Co. Ltd..

Dolar, M.L., Leatherwood, S.J., Wood, C.J., Alava, M. N. R., Hill, C. L., and Aragones, L.V. 1994. Directed Fisheries for cetaceans in the Phillippines. Reports of the International Whaling Commission, 44: 439-49. 


\section{MARINE MAMMAL EXPLOITATION}

Du Tertre, J.B. 1667. Histoire générale des Antilles habitées par les François, 4 volumes. Paris: T. Jolly.

Gaskin, D.E. and Smith, G.J.D. 1977. The Small Whale Fishery of St. Lucia, W. I. Reports of the International Whaling Commission, 27: 493.

IWC. 1997. Forty-Seventh Report of the International Whaling Commission. Cambridge, UK: International Whaling Commission.

Jackson, J.B.C. 1997. Reefs since Columbus. Coral Reefs, 16 (Suppl.):S23-S32.

Jackson, J.B.C. 2001. What was natural in the coastal oceans? Proceedings of the National Academy of Sciences (USA), 98: 5411-18.

Joseph, E L. 1838 (1970). History of Trinidad. London: Frank Cass \& Co. Ltd.

Kenny, J. S. and Bacon, P.R. 1981. Aquatic Resources. In G. C. Cooper and P. R. Bacon (eds) The natural resources of Trinidad and Tobago, pp 112-201. London: Edward Arnold.

Kingsley, C. 1871. At Last, A Christmas in the West Indies. London: MacMillan \& Co.

Labat, P. 1742. Nouveau Voyage aux Isles de l'Amerique. 4 volumes, Paris: Chez Theodore le Gras.

Lee, Z.C.Y. 1980. Water dwelling mammals. Trinidad Naturalist, 3 :3 .

Lefebvre, L.W., O’Shea,T.J., Rathbun, G.B. and Best, R.C. 1989. Distribution, status, and biogeography of the West Indian manatee. In C.A. Woods (ed) Biogeography of the West Indies. Past, Present, and Future, pp 567-609. Gainesville, FL.: Sandhill Crane Press.

Marsh, H. and Lefebvre, L.W. 1994. Sirenian status and conservation efforts. Aquatic Mammals 20: 155-70.

M'Callum, P. F. 1805. Travels Trinidad during the months of February, March, and April in a series of letters. Liverpool: W. Jones.

McKillop, H. I. 1985. Prehistoric exploitation of the manatee in the Maya and circumCaribbean areas. World Archaeology, 16: 337-53.

Meine, C. 1999. It's about time: Conservation biology and history. Conservation Biology, 13: $1-3$.

Mendes, A.L. 1932. Around Trinidad with rod, line and harpoon. Canada West Indies Magazine, 22: 18-21.

Mendes, A.L. 1937. Fisherman's paradise. The Canada-West Indies Magazine, 26: 21-4.

Mitchell, E.D. 1975. Porpoise, dolphin and small whale fisheries of the world. IUCN. Monograph No. 3 Morges, Switzerland: IUCN.

Mole, R.R. 1925. Lamantin in Port of Spain Gazette. Sept. 6, 1925. Vol. 48, (13698), p. 6.

Ottley, C.R. 1974. Slavery Days in Trinidad. A social history of the island from 17971838. Trinidad: Published by the author.

Ottley, T.; Henry, C.; Khan, A.; Siung-Chang, A. and Sturm, M. 1994. Incidents involving Whales in Trinidad waters during 1987. From the compilation: Regional Management Plan for the West Indian Manatee (Trichecus manatus). Regional Workshop on the Conservation of the West Indian Manatee in the Wider Caribbean Region. Kingston, Jamaica, 1-4 March, 1994 (reprinted in Living World. Journal of the Trinidad and Tobago Field Naturalists' Club 1987-88).

Pastor Bodmer, B. 1992. The armature of conquest. Spanish accounts of the discovery of America, 1492-1589. Stanford: Stanford University Press. 


\section{ALDEMARO ROMERO ET AL.}

Perrin, W.F., 1985. The Former Dolphin Fishery at St Helena. Reports of the International Whaling Commission, 35: 423-8.

Ponting, C. 1991. A green history of the world. The environment and the collapse of great Civilizations. New York: Penguin Books.

Price, W.S., 1985. Whaling in the Caribbean: Historical Perspective and Update. Reports of the International Whaling Commission, 35: 413-20.

Rack, R.S., 1952. Fisheries in the Caribbean. Report of the Fisheries Conference held at Kent House, Trinidad, March 24-28, 1952. Port-of-Spain, Trinidad.

Ray, C.E. 1960. The Manatee in the Lesser Antilles. Journal of Mammalogy, 41: 412-13.

Reeves, R.R. 1988. Exploitation of Cetaceans in St. Lucia, Lesser Antilles, January 1987. Reports of the International Whaling Commission, 38: 445-7.

Reeves, R.R., Khan, J. A., Olsen, R.R., Swartz, S. L. and Smith,T.D. 2001. History of whaling in Trinidad and Tobago. Journal of Cetacean Research and Management, $\mathbf{3}$ : 45-54.

Romero, A; Agudo, A.I. and Green, S.M. 1997. Exploitation of cetaceans in Venezuela. Reports of the International Whaling Commission, 47: 735-46.

Romero, A., Agudo, A.I., Green, S.M. and Notarbartolo di Sciara, G. 2001. Cetaceans of Venezuela: Their distribution and conservation status. NOAA Technical Reports NMFS, 151: 1-60.

Romero, A., S. Chilbert, \& M. G. Eisenhart. 1999. Cubagua's Pearl-Oyster Beds: The First Depletion of a Natural Resource Caused by Europeans in the American Continent. Journal of Political Ecology, 6: 57-78.

Romero, A. and Hayford, K.T. 2000. Past and present utilisation of marine mammals in Grenada, West Indies. Journal of Cetacean Research and Management, 2: 223-6.

Sale, K. 1991. The conquest of paradise. Christopher Columbus and the Columbian legacy. New York: Alfred A. Knop.

Sauer, C. O. 1966. The Early Spanish Main. Berkeley and Los Angeles: University of California Press.

Simon, J. 1997. Prophecy, plague, and plunder. The Amicus Journal, 1997: 28-33.

Swartz, S.L., Martinez, A., Cole, T., Clapham, P.J., McDonald, M.A., Hildebrand, J.A., Oleson, E.M., Burks, C. and Barlow, J. 2001. Visual and acoustic survey of humpback whales (Megaptera novaeangliae) in the Eastern and Southern Caribbean Sea: Preliminary Findings. NOAA Technical Memorandum NMFS-SEFSC, 456 1-37.

Trollope, A. 1859. The West Indies and the Spanish Main. London: Chapman \& Hall.

Turpin, E.C.S. 1978. A factual account of an incident involving porpoises. Journal of the Trinidad and Tobago Field Naturalist Club, 1978: 28-29.

Vincent, H. 1910. The Sea Fish of Trinidad. Port of Spain. New York: Press of J. J. Little \& Ives co.

Watters, D.R., Reitz, E.J., Steadman, D.W. and Pregill,G.K. 1984. Vertebrates from Archaeological sites on Barbuda, West Indies. Annals of the Carnegie Museum, 53: 383-412.

Wing, E. S. 1962. Succession of Mammalian Faunas on Trinidad, West Indies. Unpublished doctoral dissertation. University of Florida.

Wing, E.S., Hoffman, C.A. and Ray, C.E. 1968. Vertebrate remains from Indian Sites on Antigua, West Indies. Caribbean Journal of Science, 8 :123-39.

Wing, E.S. and Wing, S.R. 1995. Prehistoric ceramic age adaptation to varying diversity of animal resources along the West Indian Archipelago. Journal of Ethnobiology 15: $119-48$. 